International Journal of Electrical Engineering and Technology (IJEET)

Volume 11, Issue 4, June 2020, pp. 45-56, Article ID: IJEET_11_04_005

Available online at https://iaeme.com/Home/issue/IJEET? Volume $=11 \&$ Issue $=4$

ISSN Print: 0976-6545 and ISSN Online: 0976-6553

https://doi.org/10.34218/IJEET.11.4.2020.005

(C) IAEME Publication

Scopus Indexed

\title{
PERFORMANCE ANALYSIS OF LLC RESONANT CONVERTER INCORPORATING PI FUZZY AND NEURAL CONTROLLERS
}

\author{
N. Madhanakkumar \\ Associate Professor, Department of EEE, \\ Mailam Engineering College, India \\ T. Vasanth \\ Assistant Professor, Department of EEE, \\ Mailam Engineering College, India

\section{Sriramkumar} \\ PG Scholar in Power Electronics and Drives, \\ Mailam Engineering College, India \\ C. Kanchana \\ PG Scholar in Power Electronics and Drives, \\ Mailam Engineering College, India
}

\begin{abstract}
The existing literature predominantly concentrates on the design of the modified LLC type of resonant converter and the implementation of state space modeling. In this paper, several performance inquiries of PI, Fuzzy and Neural control have been engaged for LLC Resonant Converter. In this recommended converter an input voltage (40V) has been converted in to output voltage of $220 \mathrm{~V}$. The results of various controllers for LLC Resonant Converter have been effectively compared and calculated different Time Domain Specifications (TDS) such as Delay time, Rise time, Peak overshoot, Peak time and Settling time. It can be concluded that the performance of neural controller sensitiveness is practically less compared with PI and Fuzzy controller.
\end{abstract}

Key words: LLC Resonant Converter, PI controller, Fuzzy controller, Neural controller

Cite this Article: N. Madhanakkumar, T. Vasanth, V. Sriramkumar and C. Kanchana, Performance Analysis of LLC Resonant Converter Incorporating PI Fuzzy and Neural Controllers, International Journal of Electrical Engineering and Technology, 11(4), 2020, pp. 45-56.

https://iaeme.com/Home/issue/IJEET?Volume $=11 \&$ Issue $=4$ 


\title{
NOMENCLATURE
}

\author{
$\mathrm{V}_{\mathrm{dc}}$ - Input voltage \\ $\mathrm{V}_{\mathrm{o}}$ - Output voltage \\ $\mathrm{C}_{\mathrm{f}}$ - The Filter capacitor \\ $\mathrm{C}_{\mathrm{p}}$ - The Parallel capacitor \\ $F_{r}$ - The Resonant frequency
}

\author{
ABBREVIATION \\ PI - Proportional Integral \\ RC -Resonant converter \\ ZVS - Zero Voltage Switching \\ ZCS - Zero Current Switching \\ SRPC - Series Parallel Resonant Converter \\ PFC- Power Factor Correction \\ FLC - Fuzzy Logic Controller
}

\section{INTRODUCTION}

In recent years efforts are being made towards the improvement of DC-DC converter efficiency by reducing switching loss[1-3]. The aim of the suggested LLC converter is to deliver significant efficacy under instabilities in line and load sides [4]. The Resonant converter applications are fluorescent lamp, filament heating, SMPS, etc. The five sections of proposed work deal with; Section I- The Design procedure of Resonant Converter. Section IIDesign of PI, Fuzzy and Neural Controllers. Section III- displays the simulation results and section IV- shows Performance Analysis of different controllers. Section V-illustrates the conclusion of proposed work.

\section{RESONANT CONVERTER (RC)}

Resonant Converters (RC) have age of thirty years old and where much effort has been spent in research at university and industry levels [5-7]. It is a switching converter that includes a tank circuit which actively participates in determining the output power flow [8-10].The losses due to switching remade less by incorporating Zero voltage switching (ZVS) and basic snubber circuits. The SPRC topology combines the advantages of both parallel as well as series resonant converter [11-13]. At last, the particular regions of the tank raise some harmonics; it is used to send real power which is finally served like a tool to reduce the peak electrical stresses in load side [14]. Figure 1 shows the Circuit diagram of modified LLC Resonant Converter. 


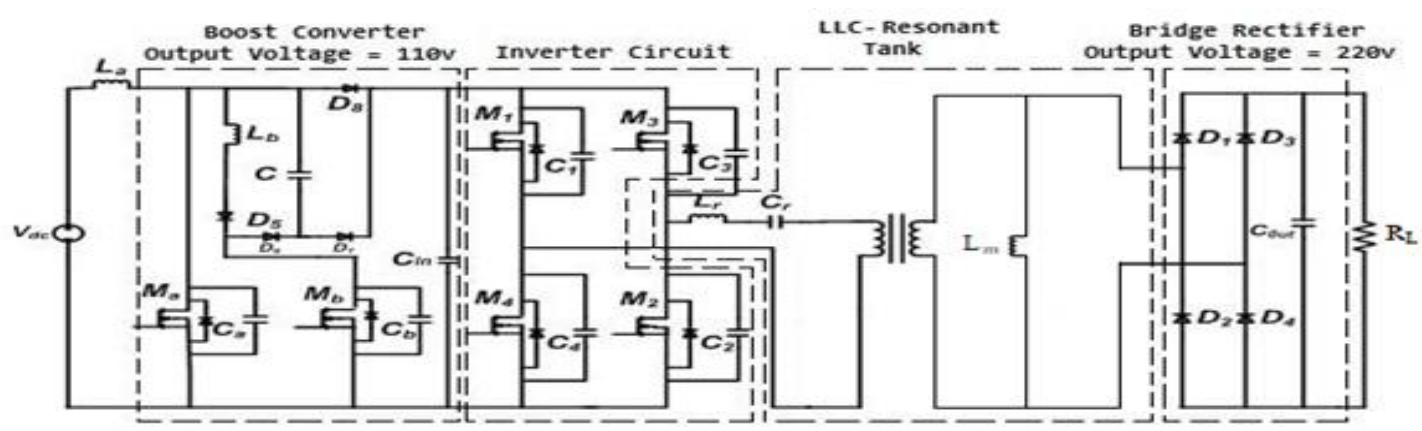

Fig 1. Circuit diagram of modified LLC Resonant - Boost Converter

\section{DESIGN OF CONTROLLERS}

\subsection{PI Controller}

The Proportional integral (PI) controller is amongst the conventional controllers. It is mostly used to control the speed. The major feature of the PI controller is the capability to keep constant zero steady-state error. The combination of PI is essential to raise the speed of the system response and to reduce the steady-state error. The circuit errors are reduced by trial and error method. The controlled signals are given to RC and Linear transformer [15]. The PI controllers are a special case; they are usually used for controlling various systems. It has some errors such as proportional and integral errors. Then the output is increased by terms of proportional constant $K_{\mathrm{p}}$. The integral error also affects the output values [16-17]. The output is increased in terms of integral constant $K_{i}$. The gain $K_{p}$ and $K_{i}$ are correcting ports to modify the preferred output response. The PI controller has the advantages of increasing system stability. Figure 2 Shows the Block diagram of LLC Resonant Converter Fed Resistive Load using PI Controller.

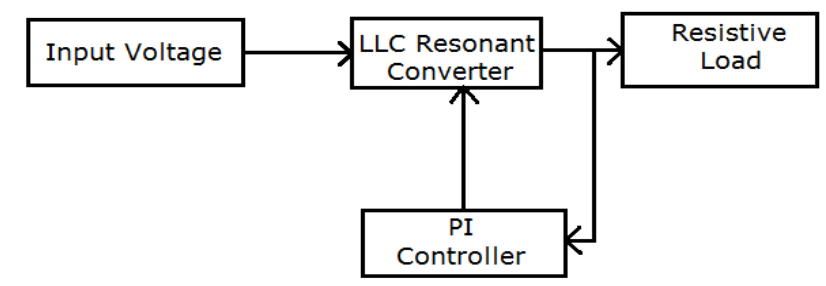

Figure 2 Block diagram of LLC Resonant Converter Fed Resistive Load using PI Controller

\subsection{Fuzzy Logic Controller (FLC)}

FLC works under the principle of FUZZY logics. Fuzzy logic provides conventional and user friendly frontend to develop the control programs. Fuzzy controllers have the tendency to oscillate around the final operating point [18].It is the processes of converting the crisp data into a linguistic member function. For the given input and output the mapping is formulated. There are seven linguistic member functions. They are NB, N, NS, ZE, PS, P, PB. It is done by using Takagi-Suge no method [19-20]. Fuzzy logic is a very powerful tool and successful implementation in every field. Fuzzy controller has several advantages over PI controller. The fuzzy controller is more beneficial because of its simple design, robust, cheap, and multiple inputs and multiple outputs. Figure 3 Shows the Block diagram of LLC Resonant Converter Fed Resistive Load using Fuzzy Controller. 


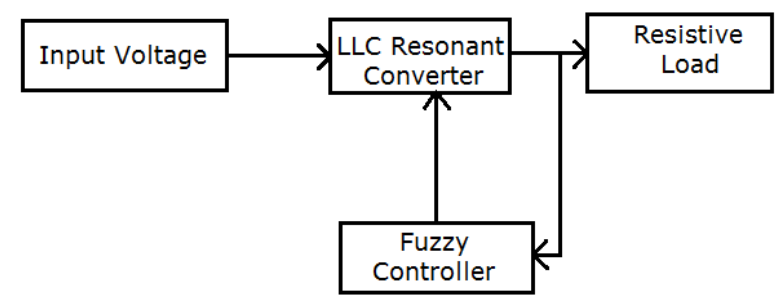

Figure 3 Block diagram of LLC Resonant Converter Fed Resistive Load using Fuzzy Controller

\subsection{Neural Controller}

The Neural Controller is subject to the Data Processing Unit. It has more interconnected processing elements. It acts as the brain of the constructed architecture. The important function of the controller is to give the preferred output. The Neural network has its own erudite and intrigue capabilities which able to adjusting the changes in data. The input and output data are important to obtain the desired output values. The data set is adequate and enough to confirm the constant operation. So there is no requirement of erudite after operation. In the Neural Controller the feedback system and pre-filters are multilayered. The Neural controller has different models such as Single input and multiple input models. The rear transmission procedure is used to run the constructed network. This procedure is commonly controlled transmission system for multilayered network. Figure 4 Shows the Block diagram of LLC Resonant Converter Fed Resistive Load using Neural Controller.

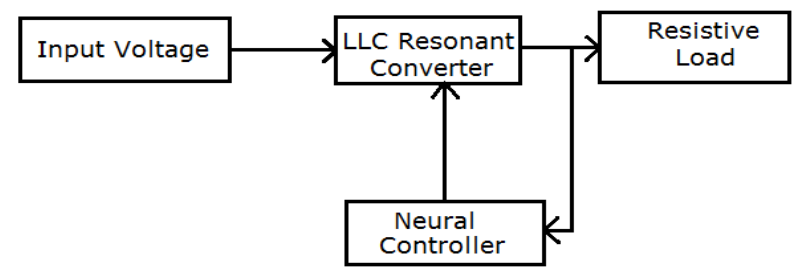

Figure 4 Block diagram of LLC Resonant Converter Fed Resistive Load using Neural Controller

\section{SIMULATION RESULTS}

The simulation results show the response of the various controllers of LLC-RC for the response of $40 \mathrm{~V}$ in load $100 \Omega$. PI, Fuzzy and Neural controller has the response of output voltage and current in line disturbance $(40 \mathrm{~V}-38 \mathrm{~V}-40 \mathrm{~V})$ at $0.55 \mathrm{sec}$ through load $100 \Omega$ and in load disturbance $(100 \Omega-90 \Omega-100 \Omega)$ at $0.55 \mathrm{sec}$ in $40 \mathrm{~V}$. Equally, the performances of the PI, Fuzzy and Neural controllers are compared with one another.

\subsection{PI Controller}

\section{Under Nil Disturbance}

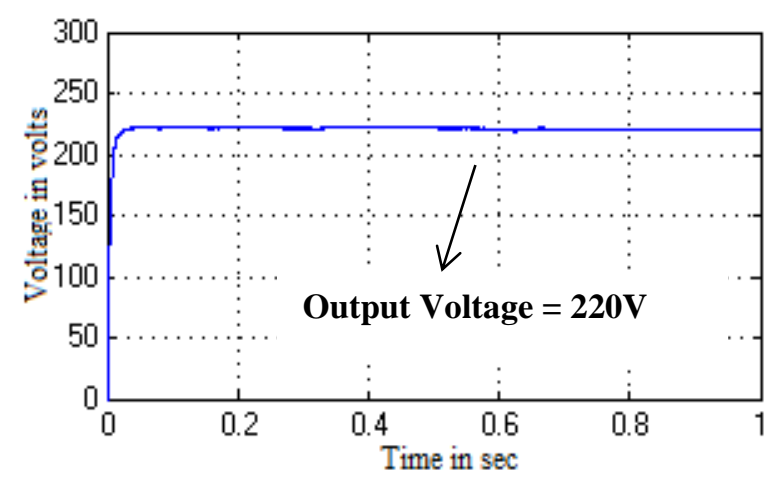


Figure 5 Simulated voltage response of LLC-RC under nominal load $100 \Omega$ and input voltage $40 \mathrm{~V}$.

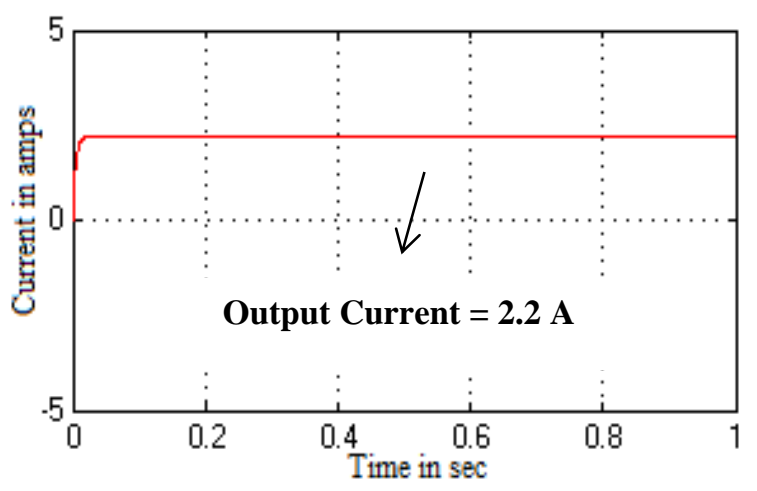

Figure 6 Simulated current response of LLC-RC under nominal load $100 \Omega$ and input voltage $40 \mathrm{~V}$.

\section{Under Line Disturbance}

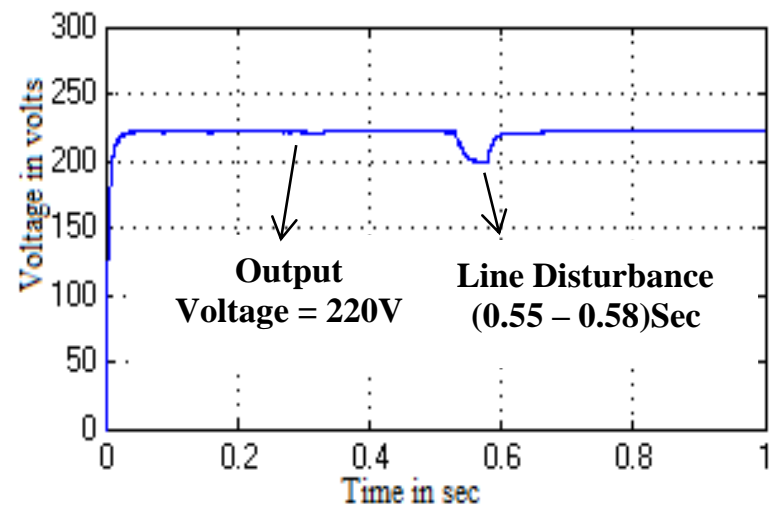

Figure 7 Simulated voltage response of LLC-RC under line disturbance $(40 \mathrm{~V}-38 \mathrm{~V}-40 \mathrm{~V})$ at $\mathrm{t}=0.55 \mathrm{sec}$.

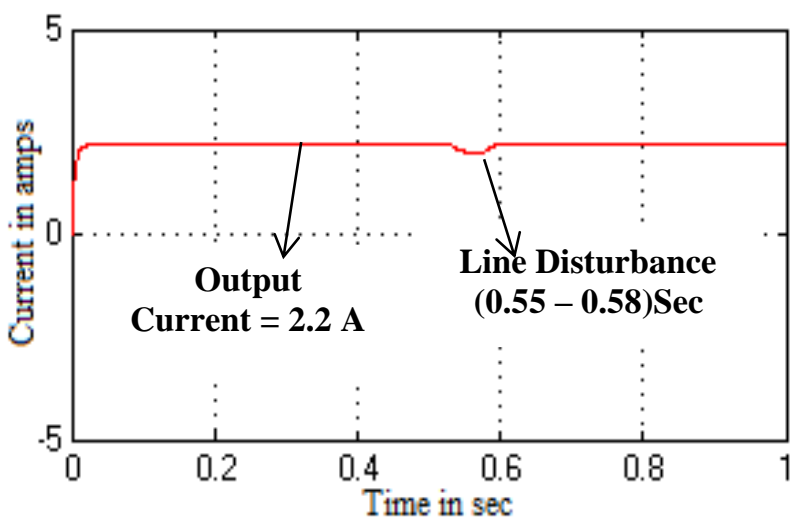

Figure 8 Simulated current response of LLC-RC under line disturbance (40V-38V-40V) at $t=0.55 \mathrm{sec}$.

\section{Under Load Disturbance}


Performance Analysis of LLC Resonant Converter Incorporating PI Fuzzy and Neural Controllers

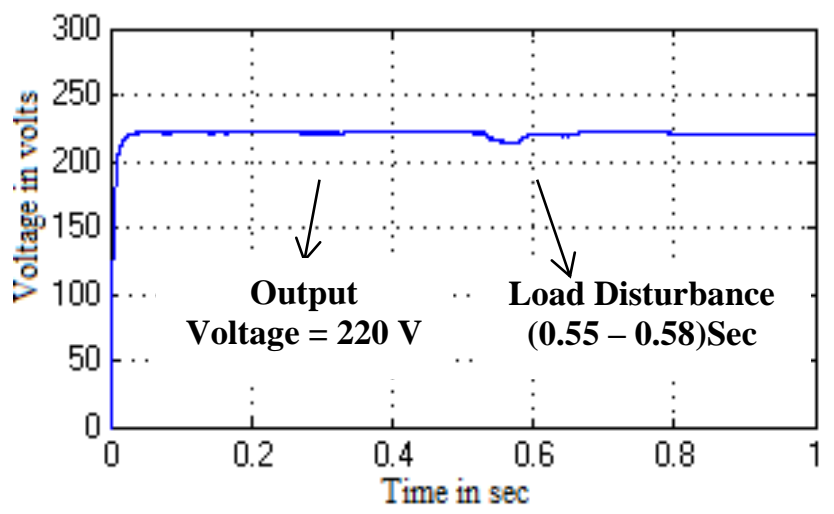

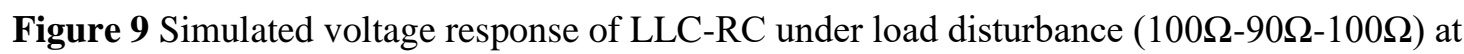
$\mathrm{t}=0.55 \mathrm{sec}$.

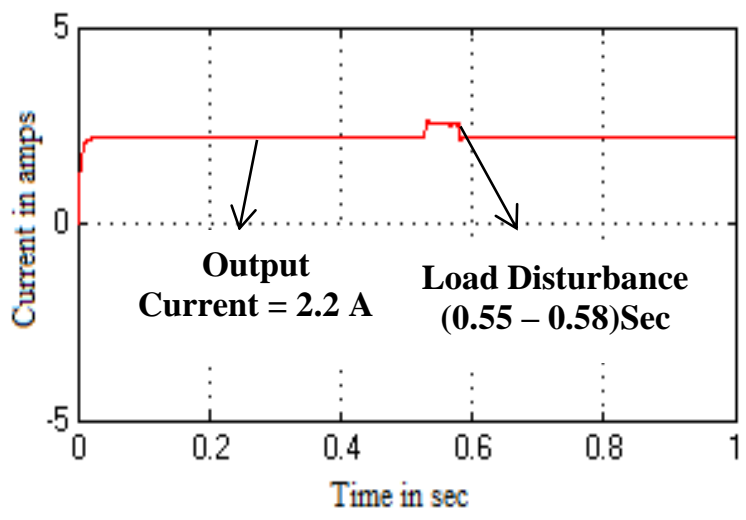

Figure 10 Simulated current response of LLC-RC under load disturbance (100 $\Omega-90 \Omega-100 \Omega)$ at $\mathrm{t}=0.55 \mathrm{sec}$.

\subsection{Fuzzy Controller}

\section{Under Nil Disturbance}

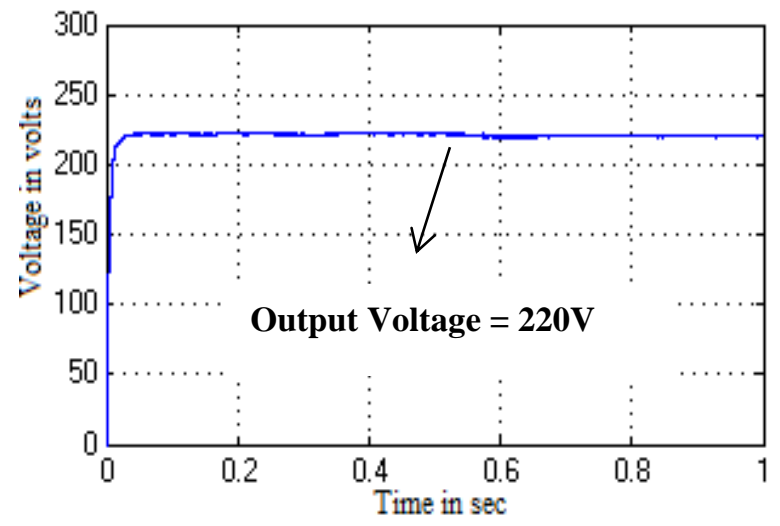

Figure 11 Simulated voltage response of LLC-RC under nominal load $100 \Omega$ and input voltage 40V. 


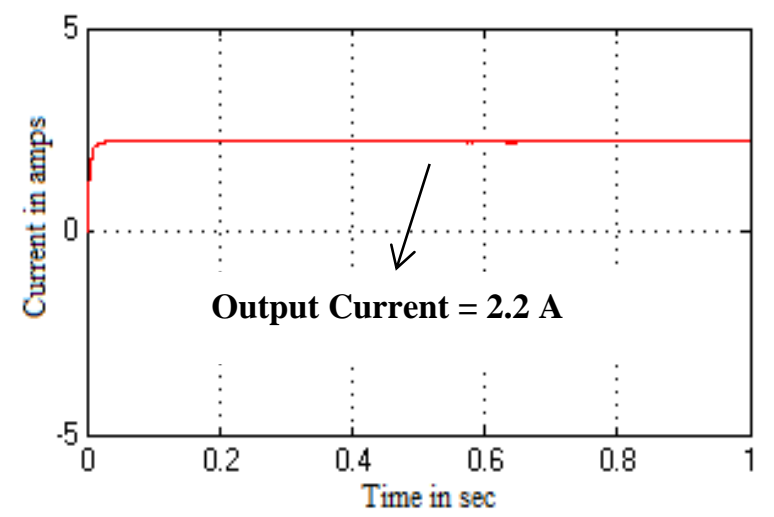

Figure 12 Simulated current response of LLC-RC under nominal load $100 \Omega$ and input voltage $40 \mathrm{~V}$.

\section{Under Line Disturbance}

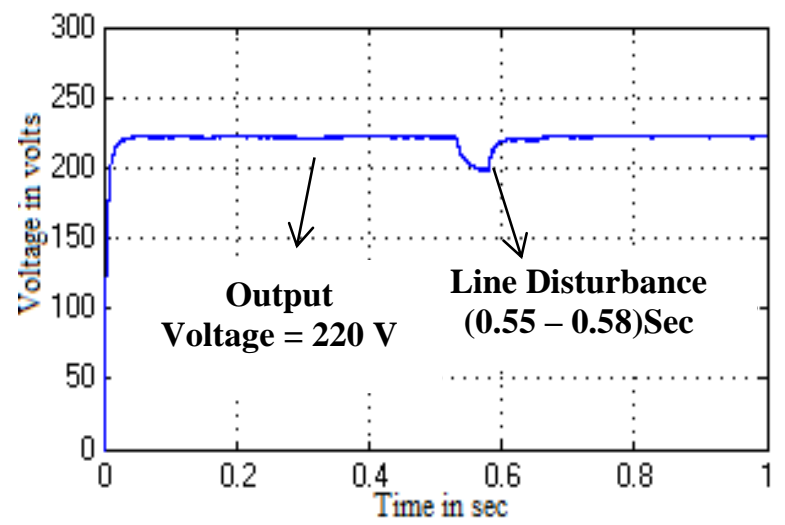

Figure 13 Simulated voltage response of LLC-RC under line disturbance (40V-38V-40V) at $\mathrm{t}=0.55 \mathrm{sec}$.

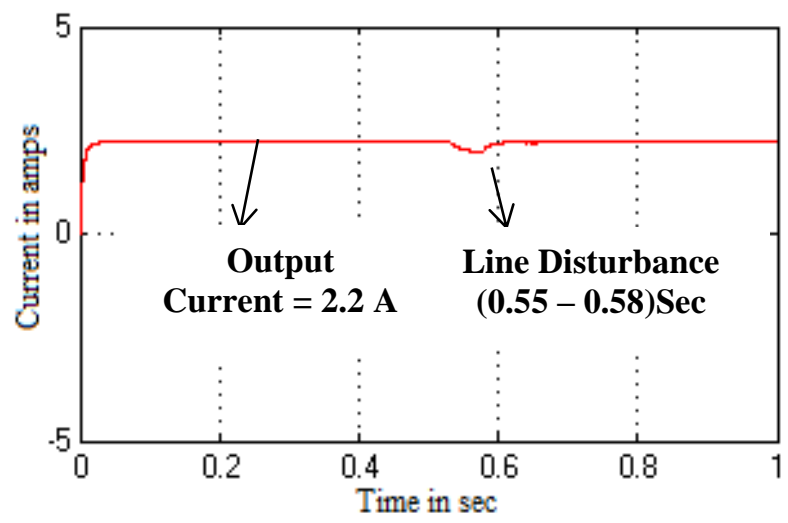

Figure 14 Simulated current response of LLC-RC under line disturbance (40V-38V-40V) at $\mathrm{t}=0.55 \mathrm{sec}$.

\section{Under Load Disturbance}


Performance Analysis of LLC Resonant Converter Incorporating PI Fuzzy and Neural Controllers

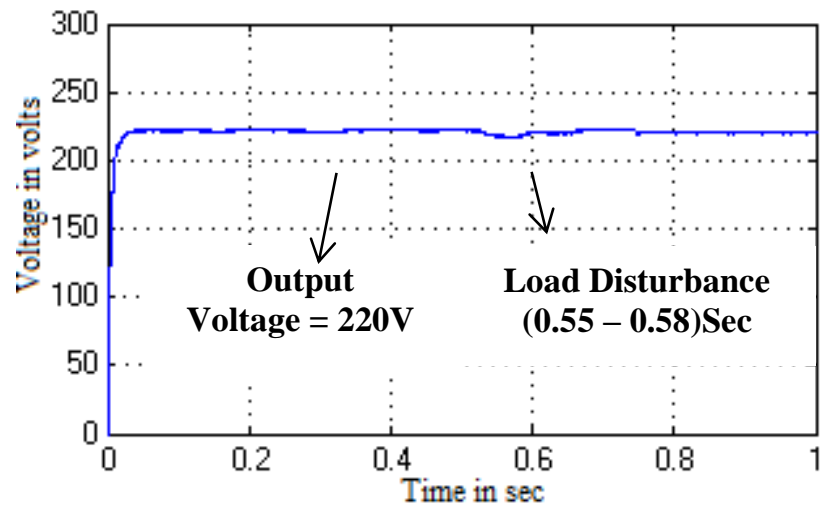

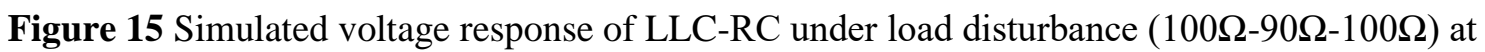
$\mathrm{t}=0.55 \mathrm{sec}$.

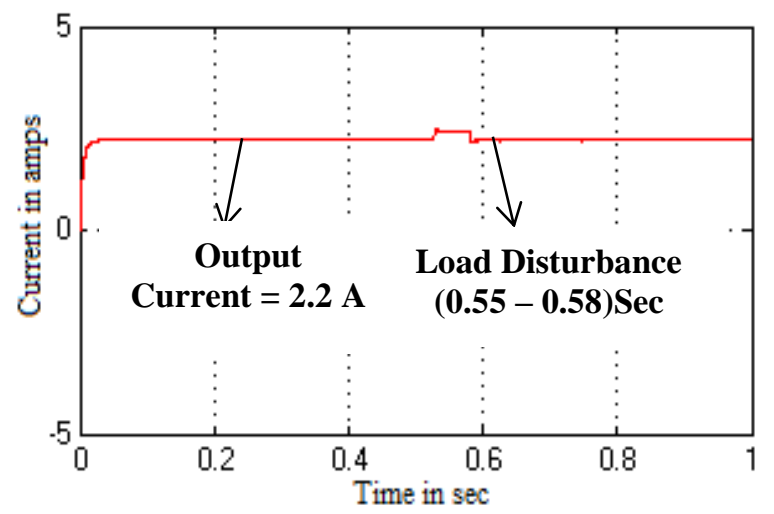

Figure 16 Simulated current response of LLC-RC under load disturbance $(100 \Omega-90 \Omega-100 \Omega)$ at $\mathrm{t}=0.55 \mathrm{sec}$.

\subsection{Neural Controller}

\section{Under Nil Disturbance}

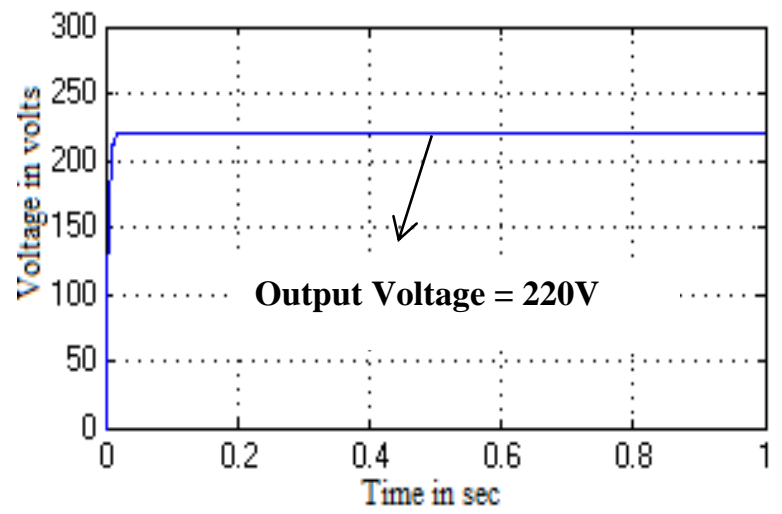

Figure 17 Simulated voltage response of LLC-RC under nominal load $100 \Omega$ and input voltage 40 V. 


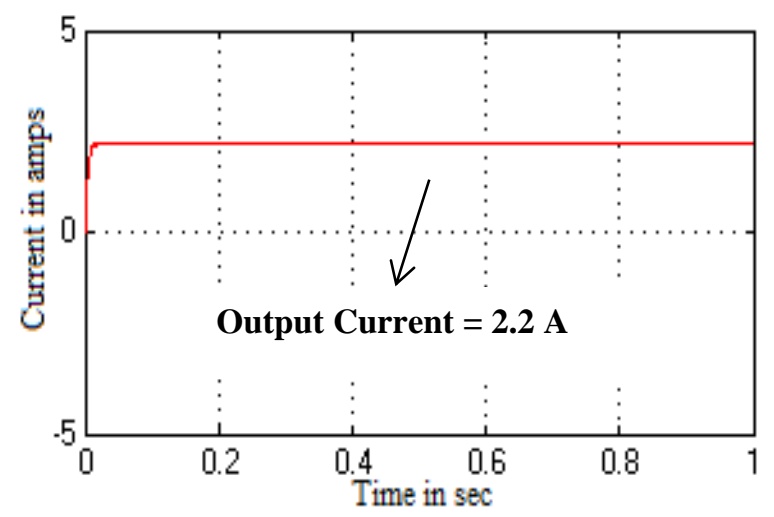

Figure 18 Simulated current response of LLC-RC under nominal load $100 \Omega$ and input voltage $40 \mathrm{~V}$.

\section{Under Line Disturbance}

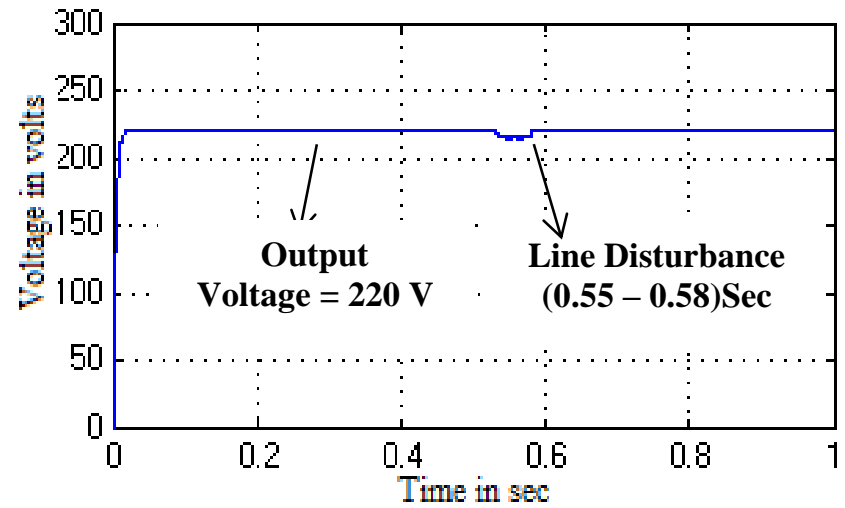

Figure 19 Simulated voltage response of LLC-RC under line disturbance (40V-38V-40V) at $\mathrm{t}=0.55 \mathrm{sec}$.

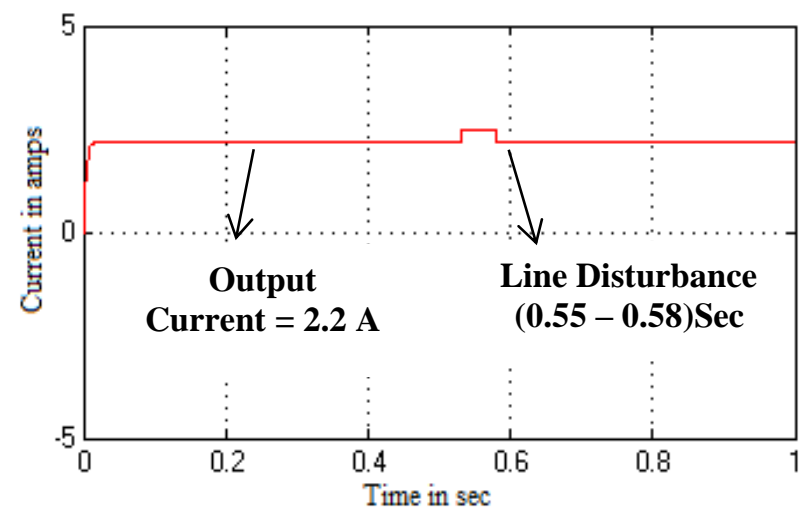

Figure 20 Simulated current response of LLC-RC under line disturbance (40V-38V-40V) at $\mathrm{t}=0.55 \mathrm{sec}$.

\section{Under Load Disturbance}


Performance Analysis of LLC Resonant Converter Incorporating PI Fuzzy and Neural Controllers

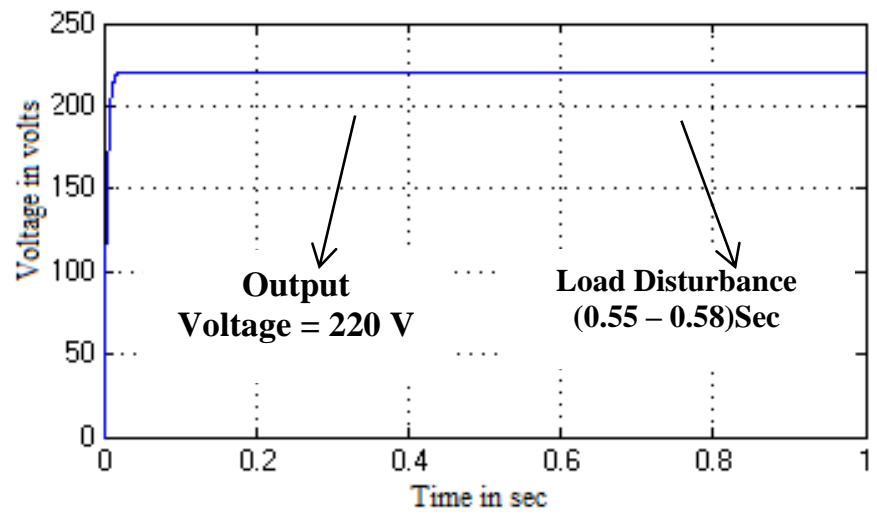

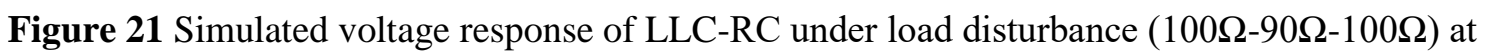
$\mathrm{t}=0.55 \mathrm{sec}$.

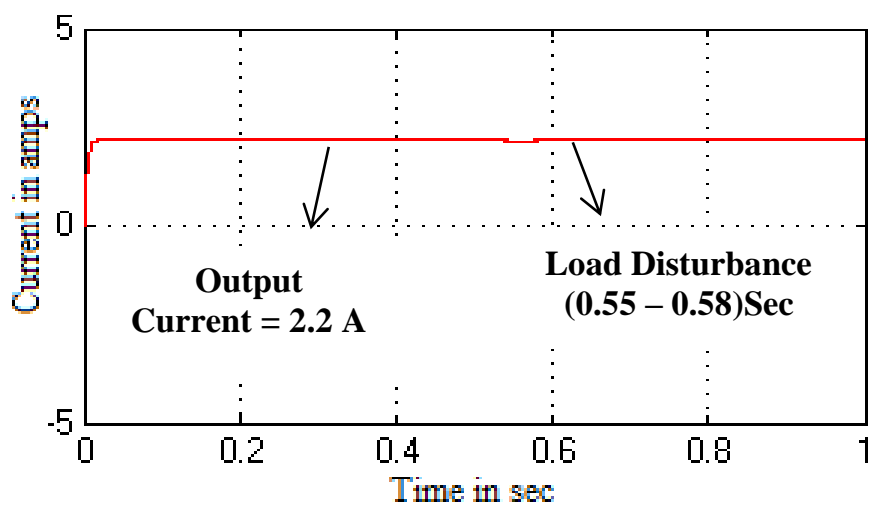

Figure 22 Simulated current response of LLC-RC under load disturbance $(100 \Omega-90 \Omega-100 \Omega)$ at $\mathrm{t}=0.55 \mathrm{sec}$.

\section{PERFORMANCE ANALYSIS}

Table.1 Represents the performance investigation of the LLC-RC under line and load disturbance with PI, Fuzzy and Neural controllers. Fig.23 shows a graphical comparison of PI, Fuzzy and Neural controller's performances of LLC-RC.

Table 1 Comparison of various parameters of different controllers under nominal load $100 \Omega$. 


\begin{tabular}{|c|c|c|c|c|c|c|c|c|c|}
\hline \multirow{2}{*}{ Controllers } & \multicolumn{5}{|c|}{ Startup transient } & \multicolumn{2}{|c|}{$\begin{array}{c}\text { Supply } \\
\text { disturbance } \\
\text { Supply decreases } \\
\text { by } \\
\mathbf{2} \text { V }\end{array}$} & \multicolumn{2}{|c|}{$\begin{array}{c}\text { Load disturbance } \\
\text { Load decreases } \\
\text { by } \\
10 \Omega\end{array}$} \\
\hline & $\begin{array}{l}\text { Delay } \\
\text { time } \\
(\mathrm{sec})\end{array}$ & $\begin{array}{l}\text { Rise } \\
\text { time } \\
(\mathrm{sec})\end{array}$ & $\begin{array}{c}\text { Peak } \\
\text { over shoot } \\
(\%)\end{array}$ & $\begin{array}{l}\text { Peak } \\
\text { time } \\
\text { (sec) }\end{array}$ & $\begin{array}{c}\text { Settling } \\
\text { time } \\
\text { (sec) }\end{array}$ & $\begin{array}{c}\text { Peak } \\
\text { over } \\
\text { shoot } \\
(\%)\end{array}$ & $\begin{array}{c}\text { Settling } \\
\text { time } \\
(\mathrm{sec})\end{array}$ & $\begin{array}{l}\text { Peak } \\
\text { over } \\
\text { shoot } \\
(\%)\end{array}$ & $\begin{array}{c}\text { Settling } \\
\text { time } \\
(\mathrm{sec})\end{array}$ \\
\hline PI & 0.02 & 0.03 & 0.025 & 0.05 & 0.055 & 0.026 & 0.06 & 0.010 & 0.06 \\
\hline FUZZY & 0.01 & 0.025 & - & - & 0.035 & - & 0.059 & - & 0.059 \\
\hline NEURAL & 0.005 & 0.01 & - & - & 0.005 & - & 0.058 & - & 0.058 \\
\hline
\end{tabular}

From the above table it was evident that Neural controller controls different Time Domain Specifications (TDS) effectively. It can be concluded that under the circumstances of supply and load disturbances, Neural controller settled down the responses faster than PI and Fuzzy controllers which is experimented by using MATLAB/SIMULINK.

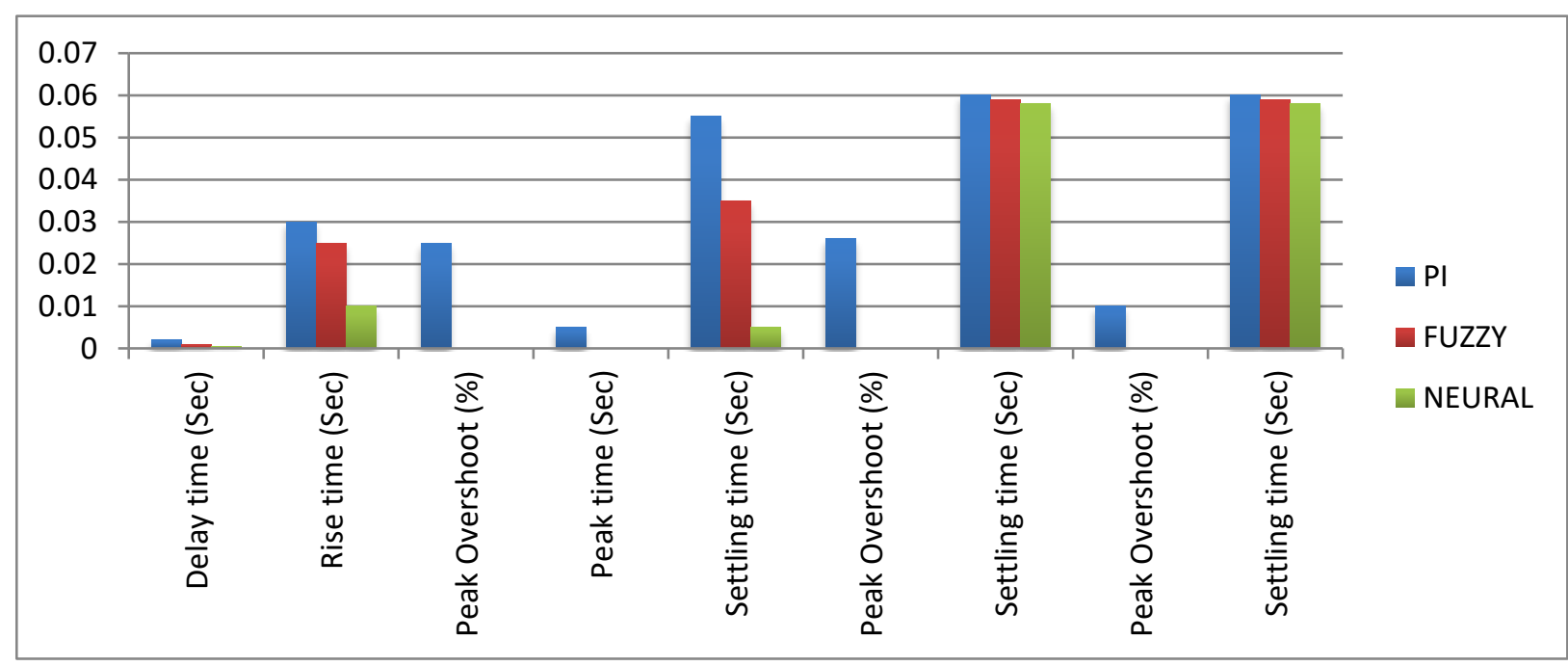

Figure 23 Comparison graph of different parameters of various controllers under nominal load $100 \Omega$.

\section{CONCLUSION}

The performance of the closed loop LLC-RC is obtained by different controllers like PI, Fuzzy and Neural. The proposed model was exposed to line disturbance (40V-38V-40V) at $\mathrm{t}=0.55 \mathrm{sec}$ under nominal load $100 \Omega$. The output voltage and current waveforms for all the

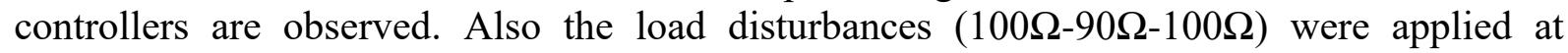
$\mathrm{t}=0.55 \mathrm{sec}$ under nominal input voltage for all the controllers and the output response were observed. The Time Domain Specifications (TDS)were calculated from the obtained results. Thus the results were compared with one another; the response of the LLC resonant converter using a neural controller gives the healthier performance than the Fuzzy and PI controller. The proposed converter maintains constant output parameters such as voltage and current in spite of various line and load disturbance. 


\section{REFERENCES}

[1] N. Madhanakkumar \& T.S. Sivakumaran, April-June 2016, 'Comparative study of closed loop control for resonant converter incorporating boost converter utilizing compression network', International Journal of Advanced Engineering Technology, vol.7, issue.2, pp. 85-92.

[2] N. Madhanakkumar \& T.S. Sivakumaran, 17 May 2016, 'Performance Analysis of PI and Fuzzy control for Modified LLC Resonant converter incorporating boost converter' Scientific Research Publishing, Circuits and Sysytems 7, pp. 835-848.

[3] Rosas-Caro, JC, Mayo-Maldonado, JC, Valderrabano-Gonzalez, A, Beltran-Carbajal, F, Ramirez-Arredondo, JM \& Rodriguez-Rodriguez, JR 2015, 'DC-DC multiplier boost converter with resonant switching', Electric Power Systems Research, vol. 119, pp. 83-90.

[4] Almeida, PM, Barbosa, PG, Oliveira, JG, Duarte, JL \& Ribeiro, PF 2015, 'Digital proportional multi-resonant current controller for improving grid-connected photovoltaic systems', Renewable Energy, vol. 76, pp. 662-669.

[5] Rui Yang, HongFa Ding, Yun Xu, Lei Yao \& Ying Meng Xiang 2014, 'An Analytical Steady -State Model of LCC type Series-Parallel Resonant Converter With Capacitive Output Filter', IEEE Transaction Power Electronics, vol. 29, no. 1, pp. 328-338.

[6] Bor-Ren Lin \& Po-Jen Cheng 2014, 'New ZVS DC-DC Converter with Series-Connected Transformers to Balance the Output Currents', IEEE Trans. Power Electronics, vol. 29, no. 1, pp. 246-255.

[7] Da Rocha, JF, dos Santos, MB \& Costa, JMD 2014, 'Voltage spikes in integrated CMOS buck DC-DC converters analysis for resonant and hard switching topologies', Procedia Technology, vol. 17, pp. 327-334.

[8] De Falco, G, Riccio, M, Breglio, G \& Irace, A 2014, 'Thermal-aware design and fault analysis of a DC/DC parallel resonant converter', Microelectronics Reliability, vol. 54, no. 9, pp. 1833-1838.

[9] Inam, W, Afridi, KK \& Perreault, DJ 2014, 'High efficiency resonant dc/dc converter utilizing a resistance compression network', IEEE Transactions on Power Electronics, vol. 29 , no. 8, pp. 4126-4135.

[10] Deepak S Gautam \& Ashoka KS Bhat 2013, 'A Comparison of Soft-Switched DC-to-DC Converters for Electrolyzer Application', IEEE Transaction Power Electronics, vol. 28, no. 1, pp. 54-63.

[11] Fang, X, Hu, H, Shen, J \& Batarseh, I 2012, 'Operation mode analysis and peak gain approximation of the LLC Resonant Converter', IEEE Transaction Power Electron, vol. 27, no. 4, pp. 1985-1995.

[12] Giri, F, El Maguiri, O, El Fadil, H \& Chaoui, FZ 2011, 'Nonlinear adaptive output feedback control of series resonant DC-DC converters', Control Engineering Practice, vol. 19, no. 10, pp. 1238-1251.

[13] Ivensky, G, Bronshtein, S \& Abramovitz, A 2011, 'Approximate analysis of resonant LLC DC-DC converter’, IEEE Transaction Power Electron, vol. 26, no. 11, pp. 3274-3284.

[14] Oeder, C 2010, 'Analysis and design of a low-profile LLC converter', in Proceeding IEEE International Symposium on Industrial Electronics, pp. 3859-3864.

[15] Martin P Foster, Christopher R Gould, Adam J Gilbert, David A Stone, \& Christopher M Bingham 2008, 'Analysis of CLL Voltage-Output Resonant Converters Using Describing Functions', IEEE Transactions Power Electronics, vol. 23, no. 4, pp. 1772-1781.

[16] Chok-Yan Chan 2007, 'A non-linear control for DC-DC power converters', IEEE Transaction Power Electronics, vol. 22, no. 1, pp. 216-222. 
[17] Ali Davoudi 2006, 'Realization of parasitics in state-space average value modeling of PWM DC-DC converters', IEEE Trans. Power Electronics, vol. 21, no. 1, pp. 1142-1147.

[18] Chen, H, Sng, EKK \& Tseng, KT 2004, 'Generalized optimal trajectory control for closed loop control of series-parallel resonant converter', in IEEE Conference Record. 0-78038399-0/04, pp. 1786-1791.

[19] Mangesh Borage, Sunil Twari \& Swarna Kotaiah 2003, 'A parallel resonant constant current power supply', Journal of Indian Institute of Science, vol. 83, pp. 117-125.

[20] Chan Ee Lyn, Rahim, NA \& Mekhilef, S 2002, 'DSP based fuzzy logic controllers for a battery charger', in IEEE Conference (TENCON'02) Record. 0-7803-7490-8/02, pp. $1512-1515$. 